\title{
GENETIC VARIATION IN CYPRINION MACROSTOMUS HECKEL, 1843 POPULATIONS AS REVEALED BY PARTIAL COI SEQUENCES OF MITOCHONDRIAL DNA
}

\author{
PARMAKSIZ, A. \\ Department of Biology, Faculty of Science-Literature, Harran University, Şanliurfa, Turkey \\ (e-mail: aprmksz@gmail.com; phone: +90-414-318-3562; fax: +90-414-318-3541) \\ (Received 23 $3^{\text {rd }}$ Dec 2017; accepted $13^{\text {th }}$ Mar 2018)
}

\begin{abstract}
Cyprinion macrostomus Heckel, 1843 naturally thriving in river systems of Euphrates and Tigris is a species with economic importance. In this study genetic diversity of C. macrostomus populations was determined based on gene sequencing analysis of mitochondrial DNA cytochrome $\mathrm{c}$ oxidase subunit I (mtDNA COI) locus. Seven polymorphic sites and eight haplotypes were detected taking 41 samples from two populations. Mean haplotype diversity $(\mathrm{h})$ and nucleotide diversity $(\pi)$ were calculated to be $h=0.529$ and $\pi=0.00158$; respectively. All values obtained from two populations after neutrality tests were calculated to be negative and were statistically insignificant ( $p>0.05$ ). Results obtained with this research are the data noted for the first time for C. macrostomus species thriving in Turkey. Certain haplotypes (H3, H5, H6, H7 and H8) determined for mtDNA COI locus are the new results to the literature and created a novel data set for genetic diversity of this species.
\end{abstract}

Keywords: Cyprinidae, genetic diversity, polymorphism, Euphrates River, Tigris River

\section{Introduction}

Euphrates and Tigris River Systems have a great deal of important capacity and potential for fish biodiversity and fishery for Turkey. Euphrates and Tigris Rivers undergo considerable change as the result of human activities. Numerous dams were built on these rivers in order to provide water for production of energy, agricultural fields and neighboring cities. Thus, differences occurring in riverbed have led to significant variation in physical, chemical, and biological composition of the river. Furthermore, environmental factors such as industrial factors, intensive fishery, and destruction of habitats will lead to extinction of several species or decrease of populations (Kuru, 1986; Ünlü et al., 1997).

Consumption of freshwater fish which are an alternative to meet protein needs of the population that has been elevating especially because Syrian immigrants have been moving to Southeastern Anatolia in recent years, has increased. The fish species preferred most by people with economically low level of income was identified to be $C$. macrostomus. Body of this fish, that is maximum $20 \mathrm{~cm}$ long, is covered by scales and laterally flattened. The mouth is large, flat, and located ventrally. Caudal fin is forked, free edges of dorsal and anal fins are concave. This omnivorous species feeds on phytoplanktons and zooplanktons (Bilici, 2009).

C. macrostomus species belonging to Cyprinidae family has distribution in Iraq, Iran, Syria, and Turkey (Kelle, 1978; Kuru, 1980). This species inhabits in Euphrates and Tigris River Systems and Orontes (Asi) River in Turkey (Kuru, 1975; Kelle, 1978; Balık, 1988; Timur et al., 1983; Tays1, 2014).

Some studies conducted on this species include; karyotype analysis in Malatya Karakaya Dam Lake by Gaffaroğlu and Yüksel (2004); hematology in Sivas Topardıç Stream and Balıklı Çermik localities by Duman and Şahan (2014); phylogenetic and phylogeographical relationship of C. macrostomus, C. kais, Carasobarbus chantrei in Euphrates and Tigris 
Rivers studied by Durna et al. (2012) via nuclear DNA-ISSR (microsatellite) and mtDNA (PZR-RFLP) methods; histological characteristics of pancreas, liver, intestines in Sivas Balıklı Hot spring by Taysı (2014); morphological differences between C. macrostomus populations in Euphrates River by Bilici et al. (2015).

C. macrostomus is caught by fishermen and has economic importance because it is consumed by local people. Genetic diversity and population structure of that species need to be known in order to manage and protect the species possessing economic importance. There is only one study (Durna et al., 2012) about genetic diversity of this fish species amongst the studies which have been carried out on C. macrostomus up to the present time, that study did not included any DNA sequencing analysis. The goal of this research is to determine genetic diversity of $C$. macrostomus populations in Euphrates and Tigris Rivers by practicing sequence analysis for mtDNA COI locus. mtDNA is generally considered to be an ideal indicator for studies of population genetics because it is maternally inherited and has rapid mutation rate (Avise, 1987). Besides its use for distinguishing similar species, mtDNA COI locus is one of the most used molecular markers for determination of the differences between populations of the same species (Croos and Palsson, 2010; Keskin and Atar, 2012).

\section{Materials and methods}

\section{Study area, sample collection, DNA extraction and amplification of mtDNA COI}

The localities of Euphrates River (Adiyaman) and Tigris River (Diyarbakır) System were found to be appropriate for sampling because of the number of populations, the availability of land conditions, the availability of sufficient number of fishermen and the proximity to the city center. 18 individuals from the Adiyaman, 23 individuals from Diyarbakır (Fig. 1), 41 in total, were caught by fishing method, transferred in to laboratory alive preserving within chambers with ice. $2 \mathrm{~g}$ specimen were dissected from muscle tissues at the base of pectoral or dorsal fins of samples caught, kept in refrigerator at $+4{ }^{\circ} \mathrm{C}$ until DNA isolation process by placing inside $1.5 \mathrm{ml}$ centrifuge tube containing $95 \%$ ethanol.

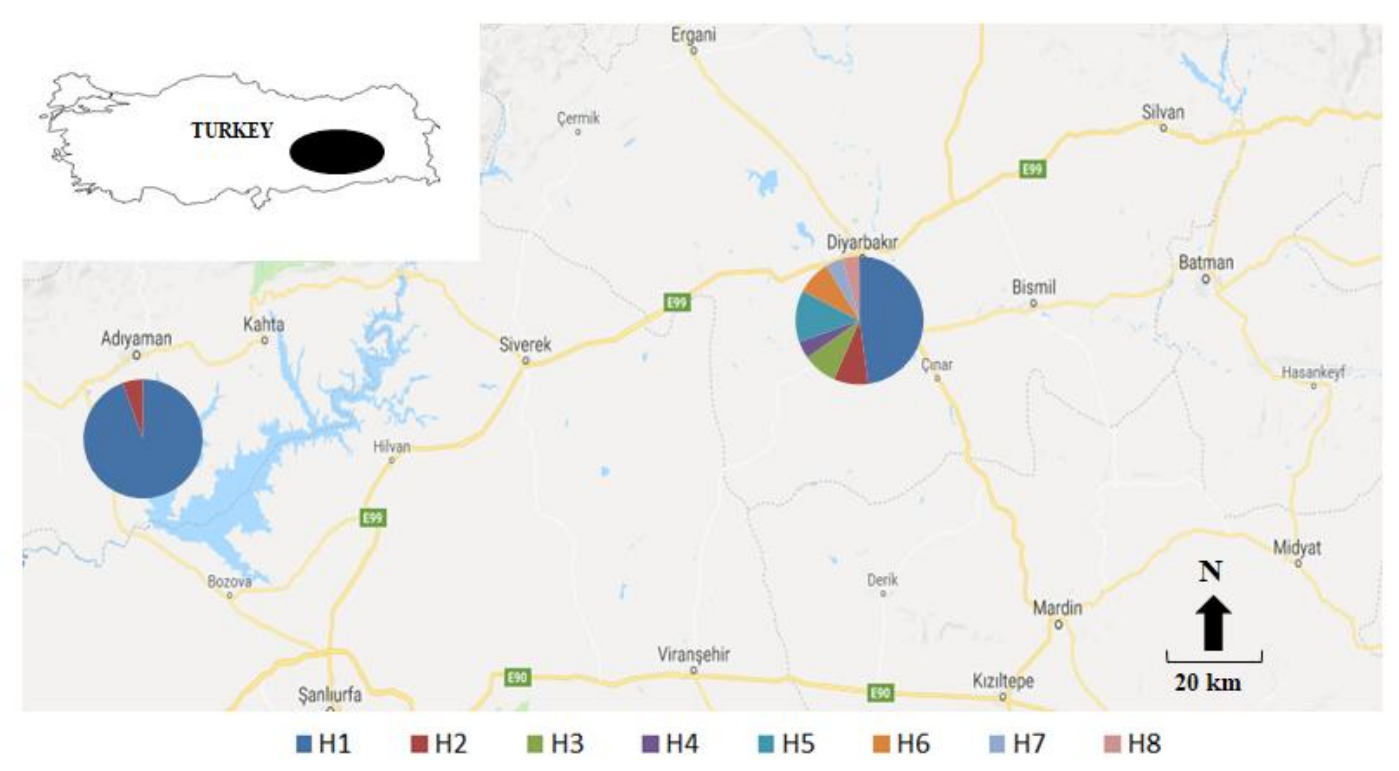

Figure 1. Location of study area and geographic distribution of haplotypes 
In this study, total DNA isolation from muscle tissue was practiced using GeneJET Genomic DNA Purification Kit (Thermo Scientific). Total DNAs were obtained by applying the protocol for this kit. In order to control the existence of DNA, $2 \mu 1$ was taken from DNA samples of each individual, placed in to tank including $0.8 \%$ agarose gel, 0.5xTBE (Tris/Boric acid/EDTA Buffer) solution with the addition of $2 \mu 1$ stain $(3 \mathrm{x}$ Loading dye) and SYBR Green, run in electrophoresis at $120 \mathrm{~V}$ for $30 \mathrm{~min}$, then viewed in device giving off ultraviolet (UV) light. The 5-end of the mtDNA COI region was amplified using the following primers: COI-625F (5'CAACCAACCACAAAGACATTGGCAC-3'), COI-625R (5'GACTTCTGGGTGGCCAAAGAATCA-3') (Darabi et al., 2014).

The PCR process was carried out by using BIO-RAD $\mathrm{T} 100^{\mathrm{TM}}$ Thermal Cycler device. Protocols of PCR were completed in totally 35 cycles including; initial denaturation at $95{ }^{\circ} \mathrm{C}$ for $3 \mathrm{~min}$, denaturation for $30 \mathrm{~s}$ at $95{ }^{\circ} \mathrm{C}, 30 \mathrm{~s}$ at $61{ }^{\circ} \mathrm{C}$ for annealing, and $45 \mathrm{~s}$ at $72{ }^{\circ} \mathrm{C}$ for extension, and finally terminated keeping specimens at $72{ }^{\circ} \mathrm{C}$ for $5 \mathrm{~min}$. PCR mixture used in order to amplify this locus is as follows; totally

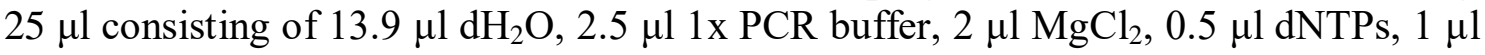
primer $(\mathrm{F}+\mathrm{R}), 0.1 \mu \mathrm{l}$ Taq polimeraz and $50 \mathrm{ng}$ template DNA. $\%$ agarose gel was used in order to check resulting products of PCR process. Sequence analysis was carried out in 3500 XL Genetic Analyzer (Thermo Fisher Scientific) by sending obtained PCR products to a commercial company.

\section{Sequence analysis of mtDNA COI}

Raw data of mtDNA sequences, which were delivered by commercial company, were evaluated and converted in to FASTA format by using ChromasPro v 2.0.1 (Technelysium Pty Ltd). Resulting sequences of all individuals in FASTA format were aligned utilizing BioEdit software version 7.2.5 program.

The number of polymorphic sites and haplotypes, diversity of haplotypes and nucleotides, Tajima D and Fu's Fs statistics were calculated for populations by using DnaSP5.10.01 program. The phylogenetic relationship between haplotypes was identified by Network version 5.0 software. Phylogenetic analyses were performed in MEGA 7 program with respect to Neighbor joining tree model using K2 parameter and phylogenetic tree was built. Bootstrap test (1000 repeats) was used for testing reliability of nodes (branches) on the tree. Sequences obtained from the present study were compared to sequences found in GenBank and phylogenetic tree was established.

\section{Results}

\section{Genetic variation}

Seven variable sites and eight haplotypes were identified by sequencing an average of $600 \mathrm{bp}$ fragments of mtDNA COI 625 locus in totally 41 C. macrostomus samples from Euphrates and Tigris Rivers. Nucleotide variations of this region are shown in Table 1. Haplotype diversity $(\mathrm{h})$, the nucleotide diversity $(\pi)$ and the neutrality tests for each population were given in Table 2 .

As seen in Table 3, totally $2(\mathrm{H} 1-\mathrm{H} 2)$ haplotypes in Euphrates population and all of the 8 haplotypes in Tigris population were indentified. Haplotype which is common in both populations and represented with the highest number of individuals is H1 (Fig. 2). 
Table 1. Nucleotide variations and haplotypes of mtDNA COI 625

\begin{tabular}{|c|c|c|c|c|c|c|c|}
\hline Haplotypes & 190 & 316 & 334 & 421 & 436 & 508 & 550 \\
\hline $\mathrm{H} 1$ & $\mathrm{~A}$ & $\mathrm{G}$ & $\mathrm{C}$ & $\mathrm{C}$ & $\mathrm{C}$ & $\mathrm{C}$ & $\mathrm{C}$ \\
\hline $\mathrm{H} 2$ & . & A & . & . & . & . & . \\
\hline $\mathrm{H} 3$ & . & A & . & $\mathrm{T}$ & . & . & . \\
\hline $\mathrm{H} 4$ & . & . & . & . & . & $\mathrm{T}$ & . \\
\hline H5 & G & . & . & . & $\mathrm{T}$ & . & . \\
\hline H6 & . & . & . & . & $\mathrm{T}$ & . & . \\
\hline $\mathrm{H} 7$ & . & A & $\mathrm{T}$ & . & . & . & . \\
\hline $\mathrm{H} 8$ & . & A & . & $\mathrm{T}$ & . & . & $\mathrm{T}$ \\
\hline
\end{tabular}

Table 2. Genetic diversity and neutrality tests of $C$. macrostomus populations ( $n=$ number of individuals, Nh: number of haplotypes, $h$ : haplotype diversity, $\pi$ : nucleotide diversity)

\begin{tabular}{c|c|c|c|c|c|c}
\hline Locality & $\mathbf{n}$ & $\mathbf{N h}$ & $\mathbf{h}$ & $\boldsymbol{\pi}$ & Tajima's D & Fu's Fs \\
\hline Euphrates River & 18 & 2 & 0.111 & 0.00018 & -1.16467 & -0.794 \\
Tigris River & 23 & 8 & 0.759 & 0.00252 & -0.67096 & -2.925 \\
Total & 41 & 8 & 0.529 & 0.00158 & -1.18176 & -3.637 \\
\hline
\end{tabular}

Mean haplotype diversity was calculated as $(\mathrm{h}=0.529)$; mean nucleotide diversity as $(\pi=0.00158)$. Population of Tigris was the one to have both higher haplotype diversity $(\mathrm{h}=0.759)$ and higher nucleotide diversity $(\pi=0.00252)$.

Table 3. The haplotypes distribution according to populations

\begin{tabular}{c|c|c|c}
\hline Haplotypes & Euphrates River & Tigris River & Total \\
\hline H1 & 17 & 11 & 28 \\
H2 & 1 & 2 & 3 \\
H3 & - & 2 & 2 \\
H4 & - & 1 & 1 \\
H5 & - & 3 & 3 \\
H6 & - & 2 & 2 \\
H7 & - & 1 & 1 \\
H8 & - & 1 & 1 \\
\hline
\end{tabular}

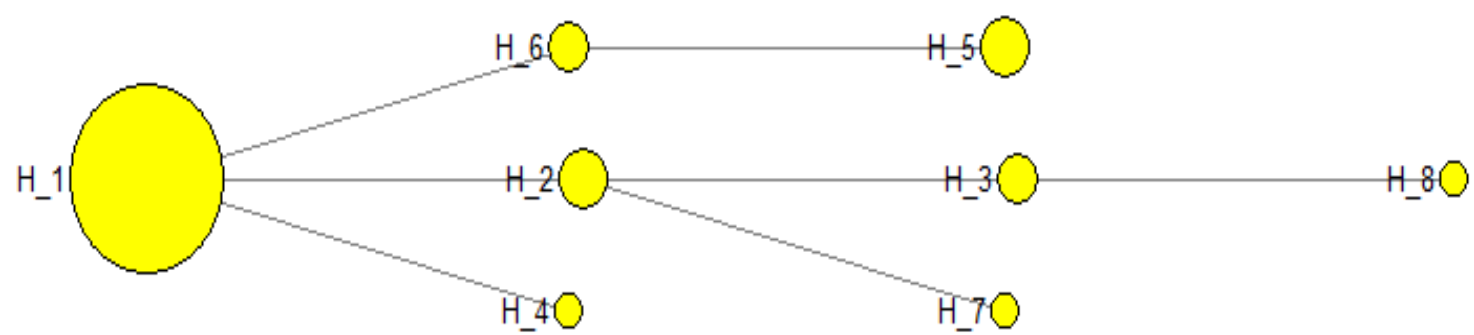

Figure 2. Haplotype network of C. macrostomus haplotypes 
Eight haplotypes in total were determined in Median-Joining Network of haplotypes created for 41 C. macrostomus samples analyzed, resulting network shows the existence of a haplotype (H1) indicating an evolutionary connection. This haplotype was detected to be the most abundant one in both of the populations (Fig. 2).

As seen in Table 4, similarities were compared by blasting $\mathrm{H} 1$ haplotype sequence, which was obtained in or study and is an ancestry one in GenBank (available at http:// blast.ncbi.nlm.nih.gov).

Table 4. Information about sequences of HI haplotype obtained in our study showing the maximum ident in GenBank

\begin{tabular}{c|c|c|c}
\hline Species & Country & Accession & Maximum ident \% \\
\hline Cyprinion $s p$. & Iranian & KM590431.1 & 100 \\
Cyprinion $s p$. & Iranian & KM590430.1 & 99 \\
Cyprinion macrostomus & Iranian & KM590433.1 & 99 \\
Cyprinion $s p$. & Iranian & KM590432.1 & 99 \\
Cyprinion $s p$. & Iranian & KM590429.1 & 98 \\
Cyprinion watsoni & Iranian & KM590434.1 & 99 \\
Cyprinion watsoni & Iranian & KM590435.1 & 99 \\
Cyprinion semiplotum & Japan & AP011253.1 & 90 \\
Cyprinion semiplotum & India & KF511536.1 & 90 \\
Cyprinion semiplotum & India & KJ957768.1 & 90 \\
\hline
\end{tabular}

Phylogenetic tree drawn based on 8 haplotypes of mtDNA COI locus from populations Euphrates and Tigris and sequences of species from genus Cyprinion in GenBank are seen in Figure 3.

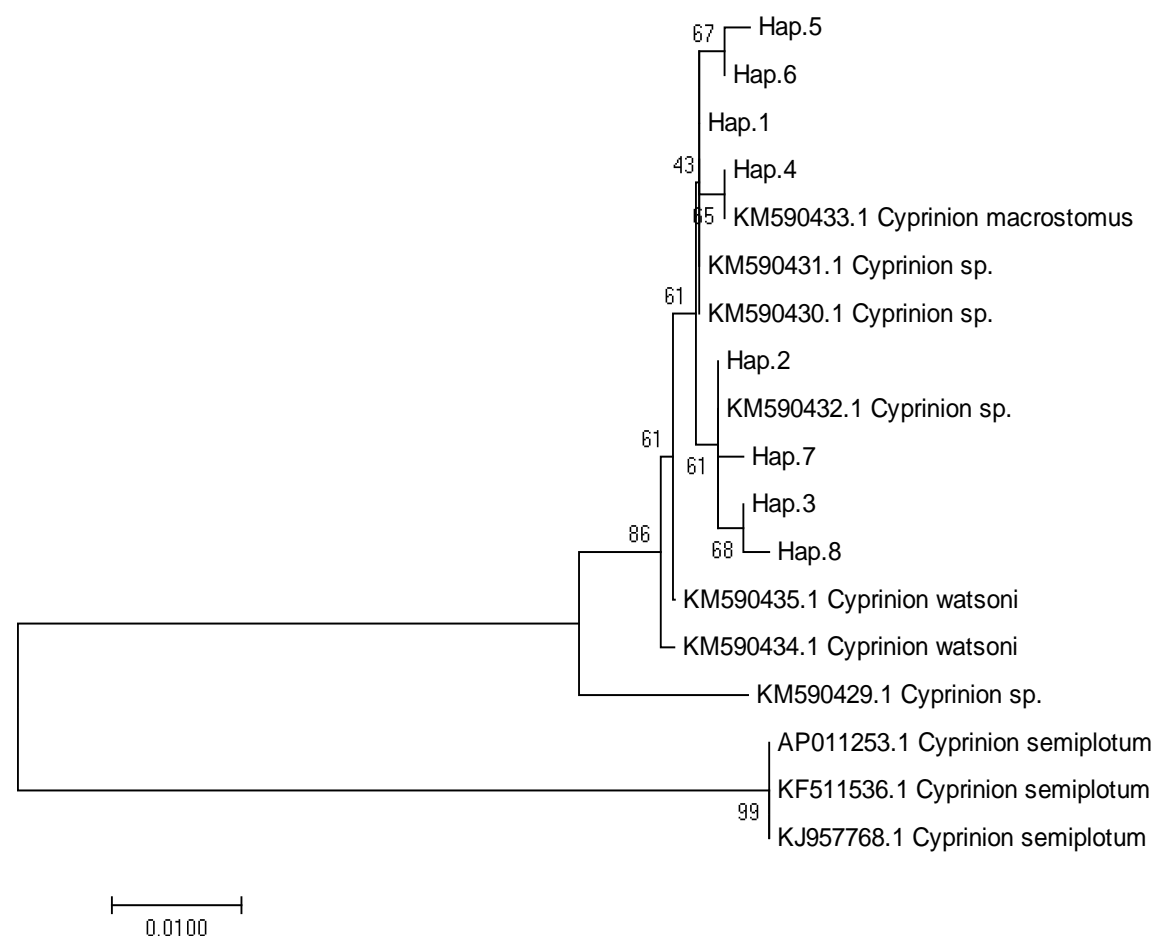

Figure 3. Neighbor-joining tree based on haplotypes of Cyprinion genus 
Two major branches are seen on the tree in Figure 3 and samples of this study and samples from Iran are placed on one branch, Cyprinion semiplotum species from India and Japan is on the other branch. Samples of Iran, Cyprinion sp (KM590430.1 and KM590431.1) have haplotype H1, Cyprinion macrostomus (KM590433.1) H4, Cyprinion sp. (KM590432.1) H2; these are similar with haplotypes in our research.

\section{Neutrality tests}

Neutrality tests are used broadly to reveal the past population history. In present study Tajima's D (1996) and Fu's Fs (1997) tests were applied for the deviation of populations from the standard neutral mode. Tajima's D value; was negative in both Euphrates (-1.16467) and Tigris (-0.67096) populations, and it was also negative in sum $(-1.18176)$ which was found to be statistically insignificant $(\mathrm{p}>0.05)$. Fu's Fs tests were negative in Euphrates (-0.794) and Tigris (-2.925) populations as well, it was also negative in sum (-3.637) and found to be statistically insignificant ( $\mathrm{p}>0.05)$.

\section{Discussion}

Genetic diversity of populations were researched in this study via sequencing mtDNA COI 625 of totally 41 C. macrostomus individuals including 18 samples from Adiyaman 23 individuals from Diyarbakır. Seven polymorphic and eight haplotypes were indentified on this locus. While only 2 haplotypes $(\mathrm{H} 1-\mathrm{H} 2)$ were found in population of Adiyaman, all haplotypes were observed in population of Diyarbakir. Different haplotype diversity of both populations results from the fact that the habitat where samples were taken was either stream or dam lake. Because, all of the individuals representing Adiyaman population were obtained from Atatürk Dam Lake, all of the individuals representing Diyarbakır population were collected from river. Since rivers have richer habitats than lakes, it is expected for Diyarbakır population to have greater genetic diversity. In addition, it is also expected for geographical isolation resulting from dams built on these rivers to lead to genetic variations between populations of fish. Haplotype H1 was seen in totally 28 individuals and it is possible to declare that haplotype $\mathrm{H} 1$ is ancestry because it is the most abundant haplotype in both populations. It was estimated that occurrence of ancestral haplotype in both populations was associated with geological localization of both rivers in the past. Upper parts of Euphrates and Tigris in Pleistosen were flowing to fresh water lakes located behind the sea retreating in late Miyosen, lower parts were flowing to inland lake, then to Persian Gulf (Demirsoy, 1999).

With the same primer, Parmaksız and Ekşi (2017) determined 6 polymorphic sites and 7 haplotypes from populations of Capoeta trutta and Parmaksiz et al. (2017) 2 polymorphic sites and 3 haplotypes from populations of Barbus grypus. The number of polymorphic sites and haplotypes in our study were higher compared to these two studies.

Data obtained as the result of analyzing mtDNA COI 625 sequences of certain fish species inhabiting in Euphrates and Tigris Rivers Systems in Turkey and data of this study were given in Table 5.

According to Table 5, both the number of haplotypes (8) and nucleotide diversity (0.00158) in this study are higher compared to other species. Nucleotide diversity is a precise method used for genetic analysis of populations (Nei and Li, 1979). Genetic diversity could be influenced by life period, characteristic of populations, environmental 
conditions and population size (Nei, 1987; Avise, 2000). Barbus grypus is the species with the lowest nucleotide variety. The reason for this is supposed to result from decreased number of individuals because it is the most fished species.

Table 5. Data of fish species studied by using mtDNA COI 625 in Turkey

\begin{tabular}{c|c|c|c|c|c|c}
\hline Species & $\mathbf{n}$ & $\mathbf{N h}$ & $\mathbf{h}$ & $\boldsymbol{\pi}$ & Tajima's D & Fu's Fs \\
\hline Capoeta trutta & 47 & 7 & 0.642 & 0.00138 & -1.08945 & -2.946 \\
Barbus grypus & 36 & 3 & 0.246 & 0.00045 & -0.91306 & -1.098 \\
Cyprinion macrostomus & 41 & 8 & 0.529 & 0.00158 & -1.18176 & -3.637 \\
\hline
\end{tabular}

In Median joining network analysis, we can see that haplotype H1 is located in the center of network and dominant, also all haplotypes are consisted of haplotype H1 (Fig. 2). We can also report that haplotype $\mathrm{H} 1$ is connected with other haplotypes on Neighbor joining tree and therefore haplotype $\mathrm{H} 1$ is ancestry haplotype (Fig. 3). In addition, mtDNA COI 625 primer distinguishes species resplendently. It placed Cyprinion watsoni and Cyprinion semiplotum species on a branch separated from Cyrinion macrostomus species.

Tajima's D ve Fu's Fs values were negative in populations of Euphrates and Tigris, all of the resulting values were not statistically significant $(p>0.05)$. These values predict that populations are in neutral balance.

All of the results obtained by this study are the data extracted for the first time for $C$. macrostomus species thriving in Turkey. Despite the fact that haplotypes H1, H2 and H4 for mtDNA COI 625 locus were determined in studies conducted in Iran, haplotypes $\mathrm{H} 3, \mathrm{H} 5, \mathrm{H} 6, \mathrm{H} 7$ and $\mathrm{H} 8$ identified in this research are new results for the literature, created a new data set for genetic diversity of this species.

\section{Conclusions}

Since the number of individuals and populations used in the present study was low, it is likely for variations by chance to occur. Therefore, it will be useful for genetic diversity of this fish species to study on greater number of individuals and more populations in further research.

Acknowledgements. This study was funded by Harran University Research Fund (HÜBAK Project No: 17219).

\section{REFERENCES}

[1] Avise, J. C. (2000): Phylogeography. - Harvard University Press, London.

[2] Avise, J. C, Arnold, J., Ball, R. M., Bermingham, E., Lamb, T., Neigel, J. E., Reeband, C. A. Saunders, N. (1987): Intraspecific phylogeography: the mitochondrial DNA bridge between population genetics and systematics. - Annu Rev Ecol Syst 18: 489-522.

[3] Balık, S. (1988): Systematic and Zoogeographical Investigation of Freshwater Fish Living in the Inland Waters of the South Anatolian Region. - Ass. Prof. Thesis, Ege University, İzmir. 
[4] Bilici, S. (2009): Variation Belonging to Morphometric and Meristic, the Study of Cyprinion macrostomus (Heckel, 1843) and Cyprinion kais (Heckel, 1843) Living in the Different Zones of Tigris River. - Master Thesis, Kafkas University, Kars.

[5] Bilici, S., Cicek, T., Baysal, A., Unlu, E., Alp, A. (2015): Morphological differences among the Cyprinion macrostomus (Cyprinidae) populations in the Tigris River. Journal of Survey in Fisheries Sciences 2(1): 67.

[6] Croos, D. M., Palsson, S. (2010): Mitochondrial DNA variation and population genetic structure of white shrimp Fenneropenaeus indicus along the coastal belt of Sri Lanka. Aquat Living Resour 23: 315-32.

[7] Darabi, A. R., Kashan, N., Fayazi, J., Aminafshar, M., Chamani, M. (2014): Investigation of phylogenetic relationship among two Barbus species (Cyprinidae) populations with mitochondrial DNA using PCR sequencing. - IJBPAS 4(2): 302-311.

[8] Demirsoy, A. (1999): General and Turkey Zoogeography “Animal Geography”, 2nd edn. - Metaksan, Ankara.

[9] Duman, S., Şahan, A. (2014): The identification of some parameters and non-specific immune respond in Cyprinion macrostomus (Heckel, 1843) living in Kangal (Sivas) Balıklı Çermik thermal hot spring and Topardıç Stream (Sivas). - Yunus Research Bulletin 4: 21-28.

[10] Durna, S., Bardakc1, F., Deger, N. (2012): Genetic diversity of Cyprinion macrostomus Heckel, 1843 (Teleostei: Cyprinidae) in Anatolia. - Turkish Journal of Fisheries and Aquatic Sciences 12: 651-659.

[11] Fu, Y. X. (1997): Statistical tests of neutrality against population growth, hitchhiking and background selection. - Genetics 147: 915-925.

[12] Gaffaroğlu, M., Yüksel, E. (2004): Karyotype analysis of Cyprinion macrostomus Heckel, 1843 (Pisces: Cyprinidae). - GÜ Kırşehir Eğitim Fak. Derg. 5: 235-239.

[13] Kelle, A. (1978): Taxonomic and Ecological Investigations on Fishes Living in the Tigris River. - PhD Thesis, Dicle University, Diyarbakır.

[14] Keskin, E., Atar, H. H. (2012): Determination of genetic variation among blue crab (Callinectes sapidus) popuations along Mediterranean coast of Turkey using COI sequences. - Journal of FisheriesSciences.com 6(2): 125-131.

[15] Kuru, M. (1975): Systematic investigations on fishes (Pisces) living in Euphrates and Tigris systems. - TÜBİTAK V. Science Congress Publications 430: 329-338.

[16] Kuru, M. (1980): Key to the inland water fishes of Turkey, Part III. - Hacettepe Bull. Nat. Sci. Eng. 9: 123-133.

[17] Kuru, M. (1986): Tigris and Euphrates Rivers will be established on the dams and threaten to fish species. - VIII. National Biology Congress, İzmir, Microbiology, Hydrobiology and Zoology Bulletin 2: 589-597.

[18] Kuru, M. (1999): Vertebrate Animals, 5th ed. - Palme Press, Ankara.

[19] Nei, M. (1987): Molecular evolutionary genetics. - Columbia University Press, New York.

[20] Nei, M., Li, W. H. (1979): Mathematical model for studying genetic variation in terms of restriction endonucleases. - Proc Natl Acad Sci 76: 5269-5273.

[21] Parmaksız, A., Ekşi, E. (2017): Genetic diversity of the cyprinid fish Capoeta trutta (Heckel, 1843) populations from Euphrates and Tigris rivers in Turkey based on mtDNA COI sequences. - Indian J. Fish. 64(1): 18-22.

[22] Parmaksı, A., Şeker, Ö., Aslan, N., Oymak, A. (2017): Determination of genetic diversity in Barbus grypus Heckel, 1843 populations by mtDNA COI gene sequences. Yunus Research Bulletin 1: 103-107.

[23] Tajima, F. (1996): The amount of DNA polymorphism maintained in a finite population when the neutral mutation rate varies among sites. - Genetics 143: 1457-1465.

[24] Timur, M., Çolak, A., Marufi, M. (1983): Identification of fish species in Sivas and investigation of the effect of skin diseases treatment. - Ankara Üniversitesi Vet. Fak. Dergisi 30(2): 276-282. 
[25] Tays1, M. R. (2014): Investigation of the properties of histological and histochemical in the spotted carp's (Cyprinion macrostomum Heckel, 1843) intestines, liver and pancreas. - Master Thesis, Firat University, Elazı ğ.

[26] Ünlü, E., Özbay, C., Kilic, A., Coskun, Y., Şeşen, R. (1997): The effects of GAP on fauna. - Turkey Environment Foundation Publications 125: 79-102. 